\title{
Hemşirelik Öğrencilerinin Bilimsel Araştırmaya Yönelik Tutumları ve Akademik Öz-Yeterlik Düzeyleri Arasındaki İlişki
}

\section{The Relationship Between the Nursing Students' Attitudes Toward Scientific Research and Their Levels of Academic Self-Efficacy}

\author{
Demet Aktaş ${ }^{1 *}$, Behire Sançar ${ }^{2}$ \\ ${ }^{1}$ Çankırı Karatekin Üniversitesi Sağlık Bilimleri Fakültesi, Çankırı, Türkiye \\ ${ }^{2}$ Toros Üniversitesi Sağlık Bilimleri Yüksekokulu, Mersin,Türkiye \\ e-mail: daktas7706@gmail.com, behiresancar@gmail.com \\ ORCID: 0000-0003-1206-4004 \\ ORCID: 0000-0003-1053-6688 \\ *Sorumlu yazar/ Corresponding Author: Demet Aktaş \\ Gönderim Tarihi / Received: 04.06.2020 \\ Kabul Tarihi / Accepted: 09.10.2020 \\ DOI: $10.34087 /$ cbusbed. 748244 \\ Öz
}

Giriş ve Amaç: Bu çalışmanın amacı hemşirelik öğrencilerinin bilimsel araştırmaya yönelik tutumları ile akademik öz-yeterlik düzeyleri arasındaki ilişkinin incelenmesidir.

Gereç ve Yöntemler: Bu çalışma kesitsel tipte tasarlanmıştır. Çalışma, Eylül 2017-Haziran 2018 tarihleri arasında Türkiye'deki bir üniversitenin hemşirelik bölümündeki 570 öğrenciyle gerçekleştirilmiştir. Veriler, Öğrenci Bilgi Formu, Bilimsel Araştırmaya Yönelik Tutum Ölçeği (BATÖ) ve Akademik Öz-yeterlik Ölçeği (AÖÖ) kullanılarak toplanmiştır.

Bulgular: Hemşirelik öğrencilerinin ortalama BATÖ skoru $91.63 \pm 13.85$ 'dir. Öğrencilerin ortalama AÖÖ puanı $19.11 \pm 3.76$ 'dır. Öğrencilerin toplam BATÖ ile AÖÖ puan ortalamaları arasında pozitif iyi derecede korelasyon saptanmıştır $(\mathrm{r}=0.416, \mathrm{p}=0.001)$.

Sonuç: Çalışmamız hemşirelik öğrencilerinin bilimsel araştırmaya yönelik tutumlarının ve akademik öz-yeterlik düzeylerinin yüksek olduğunu göstermiştir. Ayrıca, çalışmada bilimsel araştırmaya yönelik olumlu tutum ile akademik öz-yeterlik düzeyi arasında pozitif bir ilişki bulunmuştur.

Anahtar kelimeler: Akademik öz-yeterlik, Bilimsel araştırma, Bilimsel araştırmaya yönelik tutum, Hemşirelik öğrencisi

\section{Abstract}

Objective: The purpose of this study was investigated the relationship between the nursing students' attitudes toward scientific research and their levels of academic self-efficacy.

Materials and Methods: This study was designed a cross-sectional type. The study was conducted with 570 the students in the nursing department of a university in the Turkey between September 2017-June 2018. Data were collected using a Student Information Form, the Attitude Toward Scientific Research Scale (ATSRS), and the Academic Self-Efficacy Scale (ASES).

Results: The nursing students' mean ATSRS score was $91.63 \pm 13.85$. The mean ASES score of the students was $19.11 \pm 3.76$. Moderate positive correlations were detected between mean total ASES score and mean total ATSRS score in students $(\mathrm{r}=0.416, \mathrm{p}=0.001)$.

Conclusion: Our study showed that nursing students have an overall positive attitude toward scientific research and high academic self-efficacy levels. Moreover, we found a positive correlation between positive attitude toward scientific research and level of academic self-efficacy.

Keywords: Academic self-efficacy, Attitude toward scientific research, Nursing student, Scientific research.

\section{Giriş}

Scientific research is based on curiosity and the desire to learn. This thirst for knowledge has strengthened our orientation toward scientific advances through our endeavors to reveal the unknown [1,2]. Therefore, scientific advancement and professionalization are 
regarded as basic elements of scientific research [1]. Research involves the methodical generation of data $[3,4]$. In this methodical process of data generation, a problem is identified, solutions are created and applied, and the results are analyzed, compared with previous scientific data, and recorded [5-7]. However, scientific knowledge is rapidly and continuously evolving. Thus, like every profession, the nursing profession must be able to rapidly and continuously follow scientific advances and reciprocate with evidence-based scientific research in its areas of practice.

Members of the nursing profession require a certain research culture to be able to participate in studies, stay up-to-date on scientific advances, and conduct evidencebased independent/professional scientific research. To do this, individuals in information societies should be guided to develop their scientific attitudes and behaviors and participate in the research process [8]. Universities have a key role in this because via their instructors, universities have the responsibility of training students who in the future will question, conduct research, and generate new knowledge [2,3,8]. Therefore, helping nursing students gain a research-oriented perspective (applying research outcomes to clinical practice, understanding and critically evaluating research reports), creating awareness of research, giving responsibility, and developing students' identity as researchers during undergraduate education are important in terms of increasing the quality of patient care and professionalization of the nursing field $[1,9]$.

Studies have shown that when the students are given the responsibility for scientific research, they are more motivated, see the necessity of clinical research, develop competence in evaluating research outcomes, and believe that they will be able to find time to implement the research outcomes in clinical practice and will be able to gain institutional support [10-13]. In addition, another study indicated that nursing students think scientific research increases professionalism and quality of care [3]. Despite these findings, studies in the nursing field are usually conducted by academicians, and the results cannot be applied in practice to the desired extent [5]. Studies have shown that although nurses believe in the benefits of doing research, they do not believe that the research outcomes can be implemented and consider them insufficient to solve problems faced in the clinic $[11,14]$. Furthermore, it is reported that inadequacy concerning scientific research in undergraduate nursing education causes a high level of anxiety and negative perspective of conducting research $[6,14]$. Anxiety about conducting research reduces students' sense of selfefficacy $[12,13]$. However, if the student feels confident and is able to act without inhibition in subjects they are interested in, their level of self-efficacy increases $[11,12,15]$. Students' academic self-efficacy levels influence their academic success and career plans [14]. A student's belief that they can successfully fulfill their responsibilities increases their academic performance $[14,16]$. High perceived self-efficacy increases the student's motivation level and strengthens their ability to cope with new or challenging tasks $[8,10,15]$. Other studies have shown that low perceived self-efficacy caused students to leave their responsibilities unfinished and feel helpless $[11,17]$. Students who work without an effective role model in fields that are stressful and have difficult working conditions have lower perceived selfefficacy [16]. Nursing students may have reduced selfefficacy due to fear of making mistakes in both theoretical and clinical applications and having unclear expectations regarding clinical practice [18].

Nursing students will later provide healthcare services, and thus should have both a positive attitude toward scientific research and a high level of academic selfefficacy in order to be able to provide quality service. For this reason, this study was conducted to investigate the relationship between the nursing students' attitudes toward scientific research and their levels of academic self-efficacy.

\section{Materyal ve Metot \\ 2.1. Study Design}

This cross-sectional study was performed in the 20172018 academic year with volunteer students studying in the nursing department of a university in the Ankara province of Turkey.

\subsection{Study Sample and Participant Characteristics}

The study population comprised 800 nursing students. No sample selection method was used in this study. All nursing students who volunteered to participate were included in the study. The study was conducted with a sample size of 570 students $(71 \%$ of the study population). Students aged 18 years or older were included in the study.

\subsection{Data Collection Tools}

Data were collected using a student information form, the Attitude Toward Scientific Research Scale (ATSRS), and the Academic Self-Efficacy Scale (ASES). A questionnaire including these scales was given to the students by the researchers. The student information form included some sociodemographic characteristics and was prepared by the researchers based on a literature review $[1,2,6,8,18]$. The ATSRS, developed in the Turkish language by Korkmaz et al. (2011), is a 5-point Likerttype scale comprising 4 subdimensions [15]. Subdimensions of the scale include 'unwillingness to assist researchers', 'negative attitude toward research', 'positive attitude toward research', and 'positive attitude toward researchers'. High scores in the first and second subdimensions (unwillingness to assist researchers and negative attitude toward research) indicate a less favorable attitude, while high scores in the third and fourth subdimensions (positive attitude toward research and positive attitude toward researchers) indicate a more favorable attitude. Therefore, there is no overall score for the ATSRS, and only the four separate subdimension scores are calculated for this scale. Cronbach's alpha coefficient for the scale is 0.79 [15].

The ASES was developed by Jerusalem and Schwarzer (1981) [19] and its Turkish validity and reliability study was performed by Yilmaz, Gurcay, and Ekici (2007) 
[13]. It includes 7 items scored on a 4-point Likert-type scale and its Cronbach's alpha was also reported as 0.79 . 2.4. Study Procedure

After obtaining the approval of the instructors in the nursing department, the questionnaire forms were distributed by the researchers at the beginning of class. The students completed the form in about 15 minutes.

\subsection{Ethical Considerations}

Permission to conduct the study was obtained from the relevant institution and a university ethics committee. Participants included in the sample were informed about the study and their verbal consent was obtained.

\subsection{Data analysis}

SPSS version 22.0 software (SPSS Inc., Chicago, IL) was used for data analyses. Level of significance was accepted as $\mathrm{p}<0.05$. The data were expressed in frequency and percent distribution, mean, and standard deviation. Independent samples $\mathrm{t}$ test, ANOVA, and Pearson correlation analysis were used in the analyses.

\section{Results and Discussion}

Of the nursing students who participated in the study, $52,3 \%$ were 20 years of age or younger (mean 20,61 \pm 2,42 years), $85,1 \%$ were female, $28,2 \%$ were second-year students (Table 1), 98,5\% had a grade point average (GPA) of 2,01 or higher (mean 3,03 $\pm 0,15$ ), and $94.9 \%$ had graduated from general high school. We found that $64,0 \%$ of the students chose the nursing profession themselves, 56,3\% chose the profession for guaranteed work, $52,5 \%$ were satisfied with their department, and $58,6 \%$ felt a sense of belonging to the profession. It was also determined that $89,1 \%$ of the nursing students took a scientific research course during their studies, 29,5\% followed scientific publications, $74,4 \%$ were willing to conduct scientific research, $56,6 \%$ wanted to participate in scientific research for professional/personal development, and 32,2\% were unwilling to participate in scientific research due to lack of time (Table 1).

The nursing students' mean ATSRS score was 91,63 \pm 13,85 . The nursing students' mean ATSRS subdimension scores were $22,23 \pm 6,71$ for unwillingness to assist researchers, $20,37 \pm 6,90$ for negative attitude toward research, 25,09 $\pm 5,79$ for positive attitude toward research, and 23,92 \pm 4,97 for positive attitude toward researchers. In addition, the mean ASES score of the students was $19,11 \pm 3,76$ (Table 2).

In our study, mean total ATSRS and ASES scores of fourth-year students were significantly higher than those of first-, second-, and third-year students. In addition, students who expressed satisfaction with studying in the nursing department, had a sense of belonging to the profession, and were willing to conduct scientific research had higher mean ATSRS and ASES scores compared to students who responded negatively to those questions ( $\mathrm{p}<0,001$ for all) (Table 3).

Mean ATSRS and ASES scores of the nursing students did not vary significantly according to variables such as age, GPA, gender, school from which they graduated, who decided they would pursue the nursing profession, their reason for choosing the profession, and whether
Table 1. Characteristics of the Nursing Students (n: 570)

\begin{tabular}{|c|c|c|}
\hline Variables & $\mathbf{n}$ & $\%$ \\
\hline \multicolumn{3}{|l|}{ Age (years) } \\
\hline$\leq 20$ & 298 & 52,3 \\
\hline$\geq 21$ & 272 & 47,7 \\
\hline \multicolumn{3}{|l|}{ Gender } \\
\hline Female & 485 & 85,1 \\
\hline Male & 85 & 14,9 \\
\hline \multicolumn{3}{|l|}{ Year of Study } \\
\hline First & 161 & 28,2 \\
\hline Second & 160 & 28,1 \\
\hline Third & 135 & 24,6 \\
\hline Fourth & 109 & 19,1 \\
\hline \multicolumn{3}{|l|}{ Basis for choosing the profession } \\
\hline University entrance exam score & 139 & 24,4 \\
\hline Guaranteed work & 321 & 56,3 \\
\hline Love of the profession & 110 & 19,3 \\
\hline \multicolumn{3}{|l|}{ Satisfaction with department } \\
\hline Satisfied & 271 & 47,5 \\
\hline Not satisfied & 299 & 52,5 \\
\hline \multicolumn{3}{|l|}{ Sense of professional belonging } \\
\hline Yes & 334 & 58,6 \\
\hline No & 236 & 41,4 \\
\hline \multicolumn{3}{|l|}{ Taking a scientific research course } \\
\hline Yes & 61 & 10,9 \\
\hline No & 508 & 89,1 \\
\hline \multicolumn{3}{|l|}{ Following scientific publications } \\
\hline Yes & 168 & 29,5 \\
\hline No & 402 & 70,5 \\
\hline \multicolumn{3}{|c|}{ Willingness to conduct scientific research } \\
\hline Yes & 424 & 74,4 \\
\hline No & 145 & 25,6 \\
\hline \multicolumn{3}{|c|}{$\begin{array}{l}\text { Reason for wanting to participate in scientific } \\
\text { research (n: 424) }\end{array}$} \\
\hline $\begin{array}{l}\text { Professional/personal } \\
\text { development }\end{array}$ & 240 & 56,6 \\
\hline To improve quality of care & 32 & 17,1 \\
\hline $\begin{array}{l}\text { To follow scientific } \\
\text { developments }\end{array}$ & 50 & 8,8 \\
\hline For graduate education & 100 & 17,5 \\
\hline \multicolumn{3}{|c|}{$\begin{array}{l}\text { Reason for not wanting to participate in scientific } \\
\text { research (n: 145) }\end{array}$} \\
\hline $\begin{array}{l}\text { Unsuitable working } \\
\text { environment }\end{array}$ & 26 & 17,9 \\
\hline Lack of knowledge & 13 & 9,0 \\
\hline Do not consider it beneficial & 14 & 9,7 \\
\hline Lack of motivation & 41 & 28,2 \\
\hline Lack of time & 51 & 35,2 \\
\hline
\end{tabular}


Table 2. Mean ATSRS Subdimension Scores of the Nursing Students

\begin{tabular}{|l|c|c|c|}
\hline \multicolumn{1}{|c|}{ ATSRS Subdimension } & Min - Max Values & $\begin{array}{c}\text { Participants' } \\
\text { Min - Max Values }\end{array}$ & Mean \pm SD \\
\hline Unwillingness to assist researchers & $8-40$ & $8-40$ & $22,23 \pm 6,71$ \\
\hline Negative attitude towards research & $9-45$ & $9-45$ & $20,37 \pm 6,90$ \\
\hline Positive attitude towards research & $7-35$ & $7-35$ & $25,09 \pm 5,79$ \\
\hline Positive attitude towards researchers & $6-30$ & $6-30$ & $23,92 \pm 4,97$ \\
\hline Total ATSRS & $30-150$ & $40-150$ & $91,63 \pm 13,85$ \\
\hline
\end{tabular}

ATSRS: Attitude Toward Scientific Research Scale; Min. - Max.: Minumum - Maximum; SD: Standard deviation

Table 3. Comparison of Nursing Students' Mean ATSRS and ASES Scores Based On Certain Characteristics

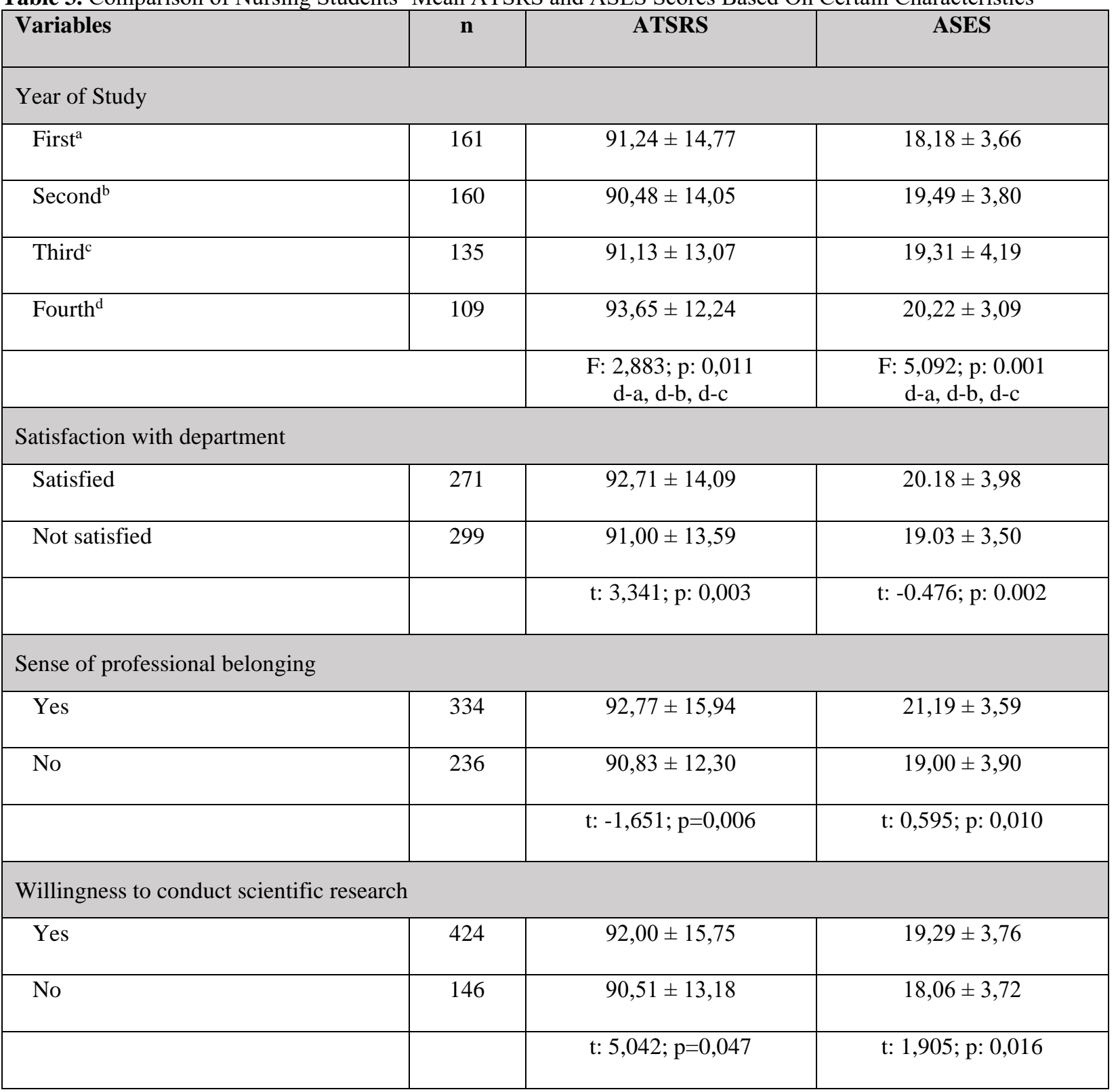

ATSRS: Attitude Toward Scientific Research Scale; ASES: Academic Self-Efficacy Scale ; t: Significance test of difference between 2 means; F: Analysis of variance; p: Statistical analysis 
they took scientific research courses or followed scientific publications $(\mathrm{p}>0,05)$.

Moderate positive correlations were detected between mean total ASES score and mean total ATSRS score (r: 0,416, p: 0,001), ATSRS positive attitude toward researchers subdimension score (r: 0,505, p: 0,001), and ATSRS positive attitude toward research subdimension score (r: 0,576, p: 0,001). In contrast, there were weak negative correlations between mean ASES score and the ATSRS unwillingness to help researchers ( $r$ : $-0,319$, p: $0,001)$ and negative attitude toward research $(\mathrm{r}:-0,226, \mathrm{p}$ : 0,001) subdimension scores (Table 4). According to this, higher ATSRS subdimension scores for positive attitude toward research and researchers were associated with higher academic self-efficacy levels. In addition, lower ATSRS subdimension scores for unwillingness to assist researchers and negative attitude toward research were also associated with greater academic self-efficacy.

Table 4. Relationship Between ATSRS and ASES Scores

\begin{tabular}{|l|l|}
\hline ATSRS & \multicolumn{1}{|c|}{ ASES } \\
\hline Unwillingness to assist researchers & $\mathrm{r}:-0,319$ \\
\cline { 2 - 2 } & $\mathrm{p}: 0,001$ \\
\hline Negative attitude towards research & $\mathrm{r}:-0,226$ \\
\cline { 2 - 2 } & $\mathrm{p}: 0,001$ \\
\hline Positive attitude towards research & $\mathrm{r}: 0,576$ \\
\cline { 2 - 2 } & $\mathrm{p}: 0,001$ \\
\hline Positive attitude towards researchers & $\mathrm{r}: 0,505$ \\
\cline { 2 - 2 } & $\mathrm{p}: 0,001$ \\
\hline Total ATSRS & $\mathrm{r}: 0,416$ \\
\cline { 2 - 2 } & $\mathrm{p}: 0,001$ \\
\hline
\end{tabular}

ATSRS: Attitude Toward Scientific Research Scale; ASES: Academic Self-Efficacy Scale; r: Correlation coefficient; p: Statistical analysis

In this study, we found that nursing students have a positive attitude toward scientific research and high academic selfefficacy levels. Studies by Celik et al. (2014) and Björkström et al. (2003) also showed that nursing students had a positive attitude toward performing scientific research [3,20]. In contrast, Ilhan et al. (2016) reported that nursing students had a negative attitude toward scientific research [1]. Our findings regarding nursing students' academic self-efficacy levels are consistent with other studies $[4,21]$. According to these results, positive attitudes toward scientific research and high levels of academic selfefficacy among nursing students can be considered favorable and desirable for the profession. This is because nursing education might have helped the students to develop an awareness of scientific research and a critical perspective.

In the present study, we observed that fourth-year nursing students had a more positive attitude toward scientific research and higher levels of academic self-efficacy compared to students in the other classes. Kes and Sahin (2019) and Unver et al. (2017) also found that fourth-year nursing students had a more positive attitude toward scientific research than more junior students [8,22]. Furthermore, studies by Karadag et al. (2011) and Zengin (2007) showed that academic self-efficacy level increases as students progress through their studies [4,23]. Similar results were also obtained in other studies [6,7]. These findings suggest that fourth-year students' attainment of greater scientific knowledge, skill, and experience may impact their willingness to follow research reports, use new information they acquire in clinical internships, and get support from academicians.

Our results indicated that students who were satisfied with studying in the department of nursing and had a sense of belonging to the profession had positive attitudes toward scientific research and high levels of academic selfefficacy. This is consistent with some earlier reports [2,14]. According to these results, satisfaction with their department and feeling that they belong and are well suited to the nursing profession increases the students' academic self-efficacy by promoting their participation in scientific activities, learning of the research process, professional self-confidence, and problem-solving and critical thinking skills.

We also found in this study that willingness to conduct scientific research was associated with a positive attitude toward scientific research and high level of academic selfefficacy. The same relationship was reported in studies by Sabzvari et al. (2009), Aydin et al. (2015), and Konuk Sener et al. (2016) [10,11,24]. Willingness to conduct scientific research may strengthen nursing students' professional knowledge and skills and enhance their academic self-efficacy.

There was a moderate positive correlation between attitudes toward scientific research and academic selfefficacy levels in the nursing students in our study. According to the results of our study, the students' academic self-efficacy level increases as their attitude toward scientific research becomes more positive. We could not find any studies in the literature that made a similar comparison. The results of our study suggest that increases in students' scientific knowledge, skill, and experience are associated with greater competence and willingness to follow research reports, participate in studies, collaborate with researchers, and implement research outcomes in patient care in the clinical setting.

\section{Conclusion}

Our study showed that nursing students have an overall positive attitude toward scientific research and high academic self-efficacy levels. Moreover, we observed a positive correlation between positive attitude toward 
scientific research and level of academic self-efficacy. The students' year of study, satisfaction with their department, sense of belonging to the profession, and willingness to conduct scientific research were also associated with their attitude toward scientific research and academic selfefficacy levels. Undergraduate nursing curricula should emphasize participation in learning activities (conferences, panels, symposiums) that foster favorable attitudes toward scientific research and promote academic self-efficacy.

\section{Acknowledgements and Disclosures}

The authors would like to thank the students who voluntarily participated in this study.

The data were collected after receiving approval from the hospital and The Clinical Research Ethics Committee of a Toros University (NO. 09/2018).

Study design: DA, BS; data collection and analysis: DA, BS and, manuscript preparation: DA, BS.

\section{References}

1.İlhan, A, Çelik, C, Aslan A, Üniversite Öğrencilerinin Bilimsel Araştırmaya Yönelik Tutumlarının İncelenmesi, İnönü University Journal of the Faculty of Education, 2016, 17 (2), 145-156.

2. Açıksöz, S, Uzun, Ș, Arslan, F, Hemşirelik Öğrencilerinde Öz Yeterlilik Algısı ile Klinik Uygulamaya İlişkin Kaygı ve Stres Durumu Arasındaki İlişkinin İncelenmesi, Gülhane Tip Dergisi, 2016, 58 (1), 129-135.

3. Çelik, S, Önder, G, Durmaz, K, Yurdusever, K, Uysal, N, Hemşirelik Öğrencilerinin Bilimsel Araștırma Yapmaya Yönelik Kaygı ve Tutumlarının Belirlenmesi, HSP, 2014, 1 (2), 23-31.

4. Karadağ, E, Derya, Y.A, Ucuzal, M, Sağlık Yüksekokulu Öğrencilerinin Öz Etkililik-Yeterlik Düzeyleri, Maltepe Üniversitesi Hemşirelik Bilim ve Sanatı Dergisi, 2011, 4 (1), 13-20.

5.Zulkosky, K, Self-Efficacy: a Concept Analysis, Nursing Forum, 2009, 44 (2), 93-102.

6. Kızılcı, S, Mert, H, Küçükgüçlü, Ö, Yardımcı, T, Hemşirelik Fakültesi Öğrencilerinin Öz Etkililik Düzeyinin Cinsiyet Açısından İncelenmesi, Dokuz Eylül Üniversitesi Hemşirelik Fakültesi Elektronik Dergisi, 2015, 8 (2), 95-100.

7. Kanat, S. Grafik Tasarım Eğitimi Alan Üniversite Öğrencilerinin Genel ve Akademik Öz-Yeterlik Algıları, YYU Journal of Education Faculty, 2018,15 (1), 790-818.

8.Kes, D, Öztürk, Şahin, Hemşirelik Öğrencilerinin Bilimsel Araştırma Yapmaya Yönelik Kaygı ve Tutumlarının Belirlenmesi, Türk Sağllk Bilimleri Dergisi, 2019, 4 (1), 68-78.

9. Saraçaloğlu, A.S, Lisansüstü Öğrencilerin Akademik Güdülenme Düzeyleri, Araştırma Kaygıları Ve Tutumları İle Araştırma Yeterlikleri Arasındaki İlişki, Yüzüncü Yll Üniversitesi Eğitim Fakültesi Dergisi, 2008, 5 (2), 179-208.

10. Sabzvari, S, Kauser, S, Khuwaja, A.K, Experiences, Attitudes and Barriers Towards Research Amongst Junior Faculty of Pakistani Medical Universities, BMC Medical Education, 2009, 9 (1), 68-74.

11. Aydın, Y, Adıgüzel, A, Altun Topal, E, Ebe ve Hemşirelerin Bilimsel Çalışmalara Yönelik Tutumlarının Belirlenmesi, Journal of Human Rhythm, 2015, 1 (4), 168-175.

12. Güzel, H, Oral, İ, Mühendis Adaylarının Akademik Öz-Yeterlik Algıları ile Fizik Başarıları Arasındaki İlişkinin İncelenmesi, International Journal of Social Science, 2017, 58 (1), 19-30.

13. Yılmaz, M, Gürçay, D, Ekici, G, Akademik Özyeterlik Ölçeğinin Türkçe'ye Uyarlanması, Hacettepe Üniversitesi Eğitim Fakültesi Dergisi, 2007, 33 (1), 253-259.

14. Konuk Sener, D, Arslan, S, Cangür, S, Aydın, M, Bir Grup Lisans Hemşirelik Öğrencisinin Mesleki Araştırma ve Gelişmelere Yönelik Farkındalık ve Tutumları, Türkiye Klinikleri Journal of Nursing Sciences, 2016, 8 (4), 317-324.

15. Korkmaz, Ö, Şahin, A, Yeşil, R, Bilimsel Araştırmaya Yönelik Tutum Ölçeği Geçerlilik ve Güvenirlik Çalışması, Elementary Education Online, 2011, 10 (3), 961-973.

16. Kürșad, M.Ș, Bilimsel Araștırmaya Yönelik Tutum ve Epistemolojik İnanç Arasındaki İlişkinin İncelenmesi, Abant İzzet Baysal Üniversitesi Ĕgitim Fakültesi Dergisi, 2015, 15 (2), 217-246.
17. Yava, A, Ciçek, H, Tosun, N, Kardiyoloji ve Kalp Damar Cerrahisi Hemşirelerinin Araştırma Sonuçlarını Kullanmalarını Etkileyen Faktörler, Anatolian Journal of Clinical Investigation, 2008, 2 (4), 160166.

18. Wangensteen, S, Johansson, I.S, Björkström, M.E, Nordström, G, Research Utilization and Critical Thinking Among Newly Graduated Nurses: Predictors For Research Use. a Quantitative Cross-Sectional Study, Journal of Clinical Nursing, 2011, 20 (17-18), 2436-2447.

19. Jerusalem, M, Schwarzer, R, Fragebogen zur Erfassung von "Selbstwirksamkeit. Skalen zur Befindlichkeit und Persoenlichkeit; Freie Universitaet, Institut fuer Psychologie. Press: Forschungsbericht, Berlin, 1981; pp 5.

20. Björkström, M.E, Johansson, I.S, Hamrin, E.K, Athlin, E.E, Swedish Nursing Students' Attitudes to and Awareness of Research and Development Within Nursing, Journal of Advanced Nursing, 2003, 41 (4), 393-402

21. Doni, N, Şimşek, Z, Gürses, G, Özer, M, Sağlık Hizmetleri Meslek Yüksekokulu Öğrencilerinin Öz Etkililik-Yeterlik Düzeyleri, Fırat Sağlk Hizmetleri Dergisi, 2009, 4 (2), 21-34.

22. Ünver, S, Semerci, R, Özkan, Z, Avcıbaşı, İ, Attitude of Nursing Students Toward Scientific Research: A Cross Sectional Study in Turkey, Journal of Nursing Research, 2017, 1 (1), 1-5.

23. Zengin, N, Sağlık Yüksekokulu Öğrencilerinde Öz-Etkililik-Yeterlilik Algısı ve Klinik Uygulamada Yaşanılan Stresle İlişsisinin İncelenmesi, Atatürk Üniversitesi Hemşirelik Yüksekokulu Dergisi, 2007, 10 (1), 4957.

24. Kocaman, G, Seren, S, Lash, A.A, Barriers to Research Utilisation by Staff Nurses in a University Hospital, Journal of Clinical Nursing, 2010, 19 (1), 1908-1918.

http://edergi.cbu.edu.tr/ojs/index.php/cbusbed isimli yazarın CBU-SBED başlıklı eseri bu Creative Commons Alınt1-Gayriticari4.0 Uluslararası Lisansı ile lisanslanmıştır.

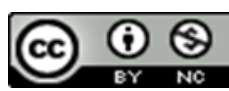

